DOI: https://doi.org/10.47405/mjssh.v5i11.535

\begin{tabular}{|c|c|}
\hline ISts & Malaysian Journal of Social Sciences and Humanities (MJSSH) \\
\hline Malaysian Journal of & Volume 5, Issue 11, November 2020 \\
\hline (MJ-ssH) & e-ISSN : 2504-8562 \\
\hline & $\begin{array}{l}\text { Journal home page: } \\
\text { www.msocialsciences.com }\end{array}$ \\
\hline
\end{tabular}

\title{
Papua Barat Sebagai Provinsi Konservasi
}

\author{
Hugo Warami ${ }^{1}$ \\ 1Universitas Papua, Indonesia \\ Correspondence: Hugo Warami (h.warami@unipa.ac.id)
}

\begin{abstract}
Abstrak
Kajian ini bertujuan mengungkap tentang upaya Pemerintah Provinsi Papua Barat dalam menghadirkan Provinsi Konservasi dalam perspektif sosial budaya. Provinsi konservasi dicanangkan dalam rangka mempertahankan kelestarian lingkungan dan kesinambungan keutuhan alam agar sumber daya alam tetap terjaga pengelolaannya serta keutuhan ekosistemnya. Sebagai produk legitimasi konstitusi, Provinsi Konservasi dalam perspektif sosial budaya dimaknai sebagai relasi antara entiti yang satu dengan entiti yang lain mampu mengekspresikan keharmonisan lingkungan melalui prinsip noken konservasi.
\end{abstract}

Kata kunci: Papua Barat, noken konservasi, budaya Austro-Melanesia

\section{West Papua as the Province of Conservation}

\begin{abstract}
This study aims to reveal the efforts of the West Papua Provincial Government in presenting the Conservation Province from a socio-cultural perspective. The conservation province was launched in the framework of maintaining environmental sustainability and natural integrity so that the management of natural resources and the integrity of the ecosystem can be maintained. As a product of constitutional legitimacy, Conservation Province in a socio-cultural perspective is interpreted as a relationship between one entity and another capable of expressing environmental harmony through the principle of noken conservation.
\end{abstract}

Keywords: West Papua, Conservation Noken, Austro-Melanesian culture

\section{Pengenalan}

Mengacu pada UU No. 32 Tahun 2009 tentang Pengelolaan Lingkungan Hidup telah dijelaskan bahwa pengelolaan lingkungan hidup adalah upaya terpadu untuk melestarikan fungsi lingkungan hidup yang meliputi kebijaksanaan penataan, pemanfaatan, pengembangan, pemeliharaan, pemulihan, pengawasan dan pengendalian lingkungan hidup. Pembangunan dengan konsep konservasi dalam perspektif sosial budaya wajib hukumnya mengacu pada pemenuhan kebutuhan generasi sekarang tanpa mengorbankan hak hidup generasi yang akan dating. Kebutuhan dan keterbatasan kemampuan lingkungan sosial budaya untuk memenuhi kebutuhan masa sekarang dan masa yang akan datang harus menjadi 
konsensus bersama dalam wacana noken konservasi. Hal ini sejalan dengan prinsip UU No. 32 Tahun 2009 tentang kesatuan ruang dengan semua benda, daya, keadaan, dan makhluk hidup, termasuk manusia dan perilakunya, yang mempengaruhi kelangsungan peri kehidupan dan kesejahteraan manusia di masa kini dan masa yang akan datang tidak mengalami pergeseran akibat kesewenangwenangan kekuasaan dan legitimasi atas komponen pengelolaan lingkungan, yakni ruang, manusia, dan aktiviti (bdk.Pilliang, 2005:370).

Fakta menggambarkan bahwa banyak penduduk Papua Barat yang tergeser dari tanah leluhurnya akibat kepentingan dan legitimasi atas nama Negara. Lebih mengerikan, bila penduduk lokal tersingkir dan terpaksa masuk dalam satu ekosistem baru yang belum tentu menjamin kesinambungan hidupnya. Misalnya, kasus pengalihan hak atas tanah untuk keperluan program transmigrasi yang telah mengurangi bahkan menghilangkan sumber-sumber ekonomi; kehilangan haiwan buruan sebagai sumber protein; kehilangan kayu untuk sumber bangunan (papan), dan rosaknya ekosistem lokal. Fakta lainnya, Suku Moi di Katapop Kabupaten Sorong kehilangan ekologi sagu sebagai sumber karbohidrat; Kasus HPH di Sorong, Teluk Wondama, Teluk Bintuni, dan Manokwari, dan lain sebagainya.

Noken merupakan warisan budaya takbenda dalam tradisi kehidupan masyarakat Papua dan menjadi bagian yang tak terpisahkan dalam kehidupan sehari-hari, dan dalam rentang waktu yang cukup panjang serta lama untuk dikonservasi kembali. Menurut Ell, dkk (2013:19-21)), Pekei (2011:64), Warami (2015:478) dan Lenny Marit Eisabeth dan Warami $(2015 ; 2018)$ menyebut bahwa warisan budaya takbenda noken pada masyarakat telah Papua mengkonstruksikan simbol-simbol yang mengandung makna-makna filsafat yang terdiri atas: (1) simbol relasi, (2) simbol kekeluargaan, (3) simbol identiti, (4) simbol perlindungan, (5) simbol ekonomi, (6) simbol kehidupan, (7) simbol estetika, dan (8) simbol spontanitas, kejujuran, keterbukaan, dan transparensi; sedangkan dalam KBBI (2011:726) terungkap bahwa konservasi adalah pemeliharaan dan perlindungan sesuatu secara teratur untuk mencegah kerosakan dan kemusnahan dengan jalan mengawetkan (pengawetan) dan pelestarian; pengelolaan sumber daya alam (hayati) dengan pemanfaatannya secara bijaksana dan menjamin kesinambungan persediaan dengan tetap memelihara dan meningkatkan kualiti nilai dan keragamannya. Merujuk pada dua konstruksi makna di atas, leksikon noken dan konservasi dipilih untuk mewadahi upaya Pemerintah Provinsi Papua Barat dalam mengeksplorasi provinsi konservasi.

Berkaitan dengan konstruksi leksikon noken dan konservasi, maka yang menjadi masalah dalam kajian ini adalah: "Bagaimana menjadikan provinsi Papua Barat sebagai provinsi konservasi dengan menjadikan prinsip noken konservasi sebagai pigura media yang mewadahi produk konstitusi secara sosial budaya Austro-Melanesia dengan prinsip perlindungan, pengawetan, dan pemanfaatan sumber daya alam secara bijaksana dan lestari serta pemulihan lingkungan hidup dan ekosistem yang telah terdegradasi”.

Adapun yang menjadi tujuan kajian ini adalah agar dapat mengidentifikasikan dan mengimplementasikan budaya Austro-Melanesia dalam mendukung noken konservasi. Budaya AustroMelanesia merupakan pertemuan dua budaya yang bermukim di wilayah Papua Barat dalam bentuk kearifan lokal yang mendasari nilai-nilai kebaikan yang dipercayai, diterapkan dan senantiasa dijaga keberlangsungannya dalam kurun waktu yang lama atau diwarisi secara turun temurun oleh pewarisnya dalam satu lingkungan atau wilayah mukimnya, dan terikat serta tunduk kepada tradisi yang berlaku dengan rasa solidaritas yang tinggi di antara para pewarisnya.

\section{Sorotan Teoritis}

Adapun yang menjadi sorotan sebagai pijakan dalam kajian ini ialah (1) teori antropologi ekologi, dan (2) terori antropolinguistik. Kedua-dua teori tersebut dapat disorot sebagai berikut. Pertama, Antropologi ekologi sebagai wacana ilmiah seperti yang kemukakan oleh Ahimsa Putra (1994:2) bahwa keberadaannya bersumber dari pelbagai peristiwa di dalam dan di luar disiplin ilmu itu sendiri. Antropologi ekologi merupakan konstruksi perpindahan dari analisis sistemik ke analisis proses (processual analisis) yang tercermin dalam pendekatan yang lebih memusatkan perhatian pada pelaku 
(actor), di mana si ahli antropologi menggunakan "actor-based mode" untuk memahami gejala yang dikaji atau telaah. Selanjutnya Ahimsa Putra (1994:4) mengemukakan bahwa ada 3 (tiga) langka dasar dalam studi antropologi ekologi (ekologi budaya) yang dikemukakan oleh Steward, yakni (1) melakukan analisis atas hubungan antara lingkungan dan teknologi pemanfaatan dan produksi, (2) melakukan analisis atas "pola-pola perilaku dalam eksploitasi suatu kawasan tertentu yang menggunakan teknologi tertentu", dan (3) melakukan analisis atas "tingkat pengaruh dari pola-pola perilaku dalam pemanfaatan lingkungan terhadap aspek-aspek lain dari kebudayaan". Kedua, Antroplinguistik merupakan studi interdisipliner yang dikembangkan oleh Duranti (1997;2003) dan Foley (1997). Selanjutnya, antropolinguistik menjadi cabang ilmu baru yang berkembang dengan sejumlah ahlinya di Indonesia. Pastika (2004:35-36) telah merekonstruksi pemikiran Duranti dan Foley menjadi 5 (lima) kerangka studi antropolinguistik, yakin (1) sebagai studi bahasa dan aktiviti budaya lainnya yang membentuk kehidupan sosial baik pada tingkat individu mahupun masyarakat, (2) studi bahasa dalam konteks antropologi, (3) mempelajari logika sistem bahasa dan aktiviti sosial tempat sistem bahasa itu digunakan, (4) kajian linguistik yang memasukkan metode dan teori antropologi untuk memetakan sistem bahasa dan sistem budaya, dan (5) suatu kajian antardisiplin yang bergantung pada (i) pentingnya bahasa untuk pemahaman budaya dan masyarakat, (ii) relevansi budaya dan fenomena sosial untuk memahami bahasa.

\section{Metod Kajian}

Desain metodologi dalam kajian ini menggunakan metode kualitatif sebagai upaya dalam proses penelitian dan pemahaman berdasarkan pada metodologi yang menyelidiki suatu fenomena sosial dan masalah kemanusiaan. Selanjutnya kajian ini menggunakan dua pendekatan, yakni (1) pendekatan teoretis dan (2) pendekatan metodologi. Pendekatan teoretis ialah eksplorasi teori Antropologi Ekologi dan Antropolinguistik, sedangkan pendekatan metodologi adalah pendekatan deskriptif dengan dimensi eksplanatif. Kajian deskriptif berupaya menggambarkan secara sistematis fakta dan karakteristik objek atau subjek yang sasar secara tepat, yakni untuk mengungkap bahasa tidak hanya sebagai apa yang dilihat, namun lebih dari itu mengungkap makna yang dikandungnya. Dalam perspektif antropologi ekologi dan antropolinguistik, kajian ini berupaya menerapkan prinsip-prinsip ilmiah terhadap data kebahasaan, serta mengadaptasi langkah-langkah dalam kajian ilmiah pada bidang ilmu lainnya. Kajian ini mengikuti prosedur (1) tahapan penyediaan data, (2) tahapan analisis data, dan (3) tahapan penyajian hasil analisis data.

\section{Hasil Kajian}

\section{Visi dan Misi Provinsi Papua Barat}

Visi Provinsi Papua Barat adalah terwujudnya masyarakat Papua Barat yang bersatu, berpendidikan dan berbudaya serta pemerintahan yang bersih dan berwibawa guna mewujudkan ekonomi kerakyatan yang demokratis, adil, sejahtera dan mandiri. Misi Provinsi Papua Barat dalam rangka mencapai Visi tersebut di atas adalah: (1) Reorientasi paradigma pembangunan: paradigma pembangunan mengacu pada pemberdayaan potensi lokal dan institusi ekonomi rakyat, (2) Revitalisasi potensi SDM dan SDA: semua potensi SDA dikelola dala perspektif untuk kemslahatan masyarakat secara fungsional, akauntabiliti, dan transparan, yang ditunjang oleh pengembangan kualiti SDM dengan kompetensi sektoral, (3) Reaktualisasi: budaya lokal menjadi pendorong dan wahana proses pembangunan semua sektor, sehingga proses pembangunan menjadi kontekstual, (4) Refungsionalisasi lembaga: pemberdayaan semua lembaga pemerintah dalam masyarakat dalam semangat kewirausahaan yang transparan dan akauntabiliti guna mendorong percepatkan pembangunan yang berbasis ekonomi kerakyatan, (5) Persatuan adalah pra-syarat yang diperlukan dalam proses pembangunan semua sektor. Keharmonisan kehidupan sosial masyarakat Papua Barat selama ini harus terus dipertahankan dan dikembangkan dengan memposisika semua komponen masyarakat dalam kebersamaan untuk berperan serta dalam proses pembangunan. Persatuan juga dimaksudkan sebagai komitmen masyarakat dan Pemerintah Papua Barat dalam kerangka Negara Kesatuan Republik Indonesia, dan (6) Perkembangan Good Goverment, iaitu pemerintahan demokratis dan penegakan supremasi hukum. 


\section{Konstruksi Provinsi Konservasi}

Provinsi konservasi merupakan wilayah pemerintahan administrasi provinsi yang menyelenggarakan pembangunan dengan menerapkan prinsip-prinsip perlindungan, pengawetan dan pemanfaatan sumber daya alam termasuk keanekaragaman hayati secara bijaksana dan lestari serta pemulihan lingkungan hidup dan ekosistem penting yang telah terdegradasi. Untuk itu, Provinsi Papua Barat sebagai salah sebuah wilayah pemerintahan di Negara Kesatuan Republik Indonesia (NKRI) yang menyelenggarakan pengelolaan sumber daya alam hayati yang pemanfaatannya dilakukan secara bijaksana untuk menjamin kesinambungan dan persediaan dengan tetap memelihara dan meningkatkan kualiti keanekaragaman dan nilai sosial budaya bagi penduduknya.

Penyelenggaraan provinsi konservasi bertujuan untuk: (a) menjamin kelestarian sumber daya alam dan ekosistemnya, (b) menjamin ketersediaan sumber daya alam sebagai modal pembangunan daerah secara berkelanjutan, (c) mempertahankan dan mengembangkan keanekaragaman hayati, (d) menjamin keseimbangan ekologi, sosial dan ekonomi dalam pembangunan, (e) mewujudkan kesejahteraan masyarakat adat di Provinsi Papua Barat secara berkelanjutan, (f) menjamin hak dan akses masyarakat adat atas sumber daya alam, (g) menjamin pelaksanaan pembangunan di Papua Barat sesuai dengan daya dukung dan daya tampung lingkungan, (h) menjamin pelaksanaan pembangunan yang selaras dengan Rencana Tata Ruang Wilayah baik darat dan perairan; (i) memperbaiki fungsi-fungsi ekologis pada kawasan yang telah terdegradasi, (j) menjamin akses terhadap sumber daya genetika dan pembahagian keuntungan yang adil dan merata dari pemanfaatan keanekaragaman hayati; (k) menjamin adaptasi dan mitigasi perubahan iklim.

\section{Pusaran Sosial Budaya Austronesia}

Migrasi sosial budaya Austronesia yang masuk dan menjadi bagian dari pola dan gaya hidup penduduk di Provinsi Papua Barat menggambarkan bahwa telah terjadi proses interaksi antara manusia dan lingkungan yang terus menerus berlangsung sepanjang waktu. Dalam konteks ini, perubahanperubahan lingkungan berdampak pada perubahan sosial budaya. Jikalau suatu lingkungan hidup yang sebelumnya masih hijau alamiah dan kaya dengan keanekaragaman hayati, kemudian berubah menjadi kawasan pemukiman dengan keanekaragaman bangunan gedung-gedung megah menjulang tinggi, bengkel-bengkel, dan pabrik-pabrik, nescaya berubah pula khazanah pengetahuan sosial budaya masyarakatnya.

Pola hidup yang materialisme di era moden menunjukkan bahwa karakteristik Austronesia yang serba konsumtif merupakan gaya hidup baru yang diyakini sebagai simbol dari modernitas. Bentaran sungai/kali penuh dengan sampah, iklim yang berubah, kelangkaan dan penurunan kualitas air bersih, bencana kekeringan, banjir, tingkat pencemaran industri yang tinggi, kerawanan pangan, hingga persoalan keanekaragaman hayati yang mulai terancam. Fenomena-fenomena di atas merupakan sebahagian persoalan lingkungan yang menjadi ancaman penduduk Papua Barat dan menambah daftar panjang persoalan kemiskinan di tengah wacana noken konservasi. Perubahan lingkungan sosial budaya bukanlah persoalan alamiah semata tetapi lebih karena perilaku sosial budaya manusia Austronesia yang tidak menghargai alam dan menempatkan alam sebagai bagian penting dalam kehidupannya.

\section{Pusaran Sosial Budaya Melanesia}

Dalam perspektif sosial budaya Melanesia, penduduk lokal tidak melakukan migrasi keluar wilayah leluhurnya ke arah wilayah Austronesia karena mereka memandang bahwa alam (bumi; kawasan; tanah; laut; dusun; kebun; hutan; pulau) menjadi inti dan titik sentral kehidupannya; sumber segala kehidupan di bumi. Pandangan sosial budaya Melanesia terbagi atas dua bagian, iaitu (1) pandangan empiris yang mencakup lingkungan alam, sumber-sumber ekonomi, dunia fauna/flora, dan manusia dapat dilihat dan disentuh; dan (2) pandangan empiris yang mencakup adanya roh-roh, kekuatan ghaib tak berkeperibadian, dan totemisme (bdk. Alua, 2006:11). Nilai sentral sosial budaya Melanesia terdiri atas empat bagian, iaitu (1) continuation of life 'kelangsungan hidup', (2) protection of life 
'perlindungan atas hidup', (3) maintenance of life 'pemeliharaan hidup', (4) celebration of life 'perayaan atas kehidupan (Alua, 2006:14).

Pandangan dan nilai sosial budaya Melanesia tentang alam alam (bumi; kawasan; tanah; laut; dusun; kebun; hutan; pulau) mengandung empat karakteristik, yakni: (1) karakter ekonomis: sebagai media yang menyediakan segenap kebutuhan dan keperluan hidupnya, mulai daripada makanan, minuman, ubat-ubatan, kayu bakar mahupun bahan untuk membuat rumah; (2) karakter budaya: sebagai mama, yakni pihak yang melahirkan dan membesarkan; oleh karenannya adalah "sah" bila sang mama menjamin kehidupan seluruh anak-anaknya dengan kesuburan dan kelimpahan kekayaan alam; (3) karakter religius: diasosiasikan dan atau dikaitkan dengan para leluhur, roh-roh dari nenek moyangnya; (4) karakter politik: bagian dari kedaulatan masyarakat. Eksistensi politik dapat diukur dari kepemilikan kawasan secara individu dan komunal.

\section{Hasil Perbincangan}

\section{Prinsip Konservasi di Kepala Burung}

Prinsip konservasi telah dijalankan sejak lama oleh beberapa suku di Kepala Burung Provinsi Papua Barat. Prinsip konservasi tersebut dapat diuraikan sebagai berikut. Pertama, suku Karoon. Suku ini memandang bahwa tanah merupakan tumpuan hidup dan penghidupan baginya, baik dari segi ekonomi, sosial, maupun budaya. Prinsip mesyuoh tapam hak kepemilikan atas tanah adat' didasarkan atas faktor keturunan atau genetis daripada pihak ayah dan ibu yang terwariskan secara turun-temurun. Pembagian tanah atau wilayah dilakukan oleh para nenek moyang dan diwariskan secara turuntemurun yang biasanya ditandai oleh sungai, gunung, dan totor 'tempat yang dianggap suci/keramat oleh klen/marga' dalam menunjukkan batas-batas hak kepemilikan atas tanah dari tiap-tiap klen/marga. Pada totor biasanya ditanami tah kek 'jenis tanaman tertentu', diberikan rahang babi, kain, piring, kadang-kadang rokok dan makanan untuk menghormati arwah yang mendiami dan menjaga tempat itu. Kedua, suku Meyah dalam kekerabatan suku besar Arfak memiliki pandangan tentang mewi 'tanah' sebagai bagian dari kehidupannya. Mewi berkaitan dengan identitas dan harga dirinya, di mana proses kelahiran, asal usul, dan berhak atasnya. Mewi dipandang sebagai (a) mewi erek mosu 'tanah bagaikan ibu kandung yang memberi kehidupan, memberi keteduhan dan kesejukan hidup", dan (b) gudang sebagai tempat penyimpanan makanan dan modal investasi masa depan. Ketiga, suku Hattam dalam kekerabatan suku besar Arfak memiliki kemiripan pola pembagian kawasan (tanah) yang sama dengan sub-sub suku lainya. Pola pembagiannya terdiri atas: (a) kawasan pusat pemukiman (kampung), (b) kawasan situmti 'kebun batas tepi pemukiman', (c) kawasan kebun luar, (d) kawasan daur-ulang, (e) kawasan nimahanti 'bekas kebun', (f) kawasan bahamti 'kawasan hutan asli/primer', dan (g) kawasan susti 'kawasan pengelolaan yang bisa digarap sebagai ladang atau kebun'. Keempat, suku Maya di Raja Ampat dikenal istilah sasi. Sistem sasi merupakan suatu larangan yang berhubungan dengan tradisi atau adat istiadat Misool. Sasi dilakukan oleh masyarakat adat yang melibatkan tokoh adat, tokoh agama dan tokoh masyarakat yang mendiami sebagian besar pesisir pulau-pulau di Misool. Sistem sasi itu dilakukan pada tempat-tempat yang telah disepakati bersama oleh tokoh-tokoh dan masyarakat di wilayah tersebut. Sasi dibuat untuk membatasi pengambilan dan memberikan kesempatan kepada biota-biota yang hidup di wilayah sasi untuk berkembang biak. Proses pembuatan sasi dilakukan dengan upacara adat, seperti pemasangan "Samsom" atau yang dikenal dengan sebutan "siri pinang" yang dipimpin langsung oleh ketua adat bersama dengan masyarakat adat yang ada di wilayah itu.

\section{Prinsip Konservasi di Teluk Cenderawasih}

Fakta pada beberapa suku yang memiliki prinsip konservasi di Teluk Cenderawasih yang disebut dengan sistem ekomaritim atau ekobahari yang memandang bahwa air laut, kerang/siput, ikan laut, ikan duyung, penyu, belut laut, dan lain sebagainya sebagai rumah dan leluhur yang wajib dijaga dan dilestarikan keberadaannya. Misalnya, inmampi ( $r$ ' 'ikan tarusi' sebagai totem dalam keret Singgamui, ikan duyung 'putri laut', penyu 'putri' siput/kerang laut 'bia garuk'. Prinsi-prinsip ini menggambarkan bahwa hubungan antara manusia dan alam (dunia laut) sangat berkaitan erat sekali. Sistem konservasi ini menjadikannya sekaligus sebagai totem in mampi( $r$ ) yang dianggap sebagai leluhur perempuan dan 
Singgaтиi 'ular putih' adalah leluhur laki-laki. Totem air laut dipandang sebagai rumah bagi manusia yang harus dijaga kelestrariannya; Penyu dipandang sebegai putri laut yang menjaga kawasan-kasawan taman laut (Lihat Erari, 1999:86).

Konservasi di Teluk Cenderwasih menurut Bawole dan Warami (2016:66-67) mengandung prinsipprinsip konservasi kawasan, yakni kawasan suaka alam, pelestarian alam, dan cagar budaya. Kawasankawasn itu mencakup: (1) Kawasan cagar alam, yaitu Kawasan Cagar Alam Pegunungan Wondiboy dengan luas kurang lebih 74.030 ha meliputi Distrik Teluk Duairi, Distrik Wasior, Distrik Wondiboy, dan Distrik Rasiei. Kawasan cagar alam (CA) ialah kawasan suaka alam yang karena keadaan alamnya mempunyai kekhasan tumbuhan, satwa, dan ekosistemnya atau ekosistem tertentu yang perlu dilindungi dan perkembangannya berlangsung secara alami. Pada kawasan hutan cagar alam tidak diperkenankan adanya upaya pemanfaatan dalam bentuk apapun termasuk kegiatan rehabilitasi. Hal ini dimaksudkan untuk menjaga kekhasan, keaslian, keunikan dan keterwakilan dari jenis flora dan fauna serta ekosistemnya. Kegiatan yang dapat dilaksanakan di kawasan cagar alam adalah kegiatan untuk kepentingan penelitian dan pengembangan, ilmu pengetahuan, pendidikan dan kegiatan lainnya yang menunjang budidaya. Fungsi penunjang budidaya dapat dilaksanakan dalam bentuk penggunaan plasma nutfah yang terdapat dalam cagar alam yang bersangkutan untuk keperluan pemuliaan jenis dan penangkaran. Kriteria cagar alam sebagai berikut: (a) mempunyai keanekaragaman jenis tumbuhan dan satwa serta tipe ekosistem; (b) mewakili formasi biota tertentu dan atau unit-unit penyusunnya; (c) mempunyai kondisi alam baik biota mahupun fiziknya yang masih asli dan tidak atau belum diganggu manusia; (d) mempunyai luas yang cukup dan bentuk tertentu agar menunjang pengelolaan yang efektif dan menjamin berlangsungnya proses ekologis secara alami; (d) mempunyai ciri khas, potensi dan dapat merupakan contoh ekosistem yang keberadaannya memerlukan upaya konservasi; dan (e) mempunyai komunitas tumbuhan dan atau satwa beserta ekosistemnya yang langka atau yang keberadaannya terancam punah. (2) Kawasan taman nasional laut, yaitu Kawasan Taman Nasional Laut Teluk Cenderawasih termasuk di dalamnya hutan suaka alam di Pulau Roon dengan luas kurang lebih 5.669 ha dan Pulau Rumberpon dengan luas kurang lebih 6.157 ha. Kawasan Taman Nasional Teluk Cendrawasih (TNTC) yang terletak di Kabupaten Teluk Wondama Provinsi Papua Barat hingga Kabupaten Nabire Provinsi Papua yang memanjang dengan garis pantai kurang lebih $500 \mathrm{Km}$ dengan luas daratan mencapai 68.200 ha, luas laut 1.385.300 Ha dengan rincian 80.000 Ha kawasan terumbu karang dan 12.400 Ha lautan. (3) Kawasan cagar budaya, meliputi: (1) kawasan pendidikan pertama di tanah Papua yang terletak di bukit Aitumeri, Distrik Wasior; (2) gua bersejarah Suku Numfor di Pulau Mioswar, Distrik Roswar; dan (3) perkampungan penduduk di atas air dan gereja tua di Desa Yende, Distrik Roon. Perlindungan terhadap kawasan cagar budaya dan ilmu pengetahuan dilakukan untuk melindungi kekayaan budaya bangsa berupa peninggalan-peninggalan sejarah, bangunan arkeologi dan monumen nasional, serta keanekaragaman bentukan geologi yang berguna untuk pengembangan ilmu pengetahuan dari ancaman kepunahan yang disebabkan oleh kegiatan alam maupun manusia.

\section{Tantangan Noken Konservasi}

Proses dekonstrusi relasi sosial budaya dalam post-environment bagi penduduk di Papua Barat yang heterogen dan plural, serta keberhasilan relasi antarbudaya yang ditentukan oleh sejauh mana penduduk lokal terlibat dalam interaksi dan komunikasi dalam menghargai heterogenitas atau pluralitas. Relasi sosial budaya yang baik dapat menciptakan iklim demokrasi yang dialogis. Akan tetapi, dalam upaya menciptakan iklim yang dialogis tersebut dapat dihambat oleh beberapa faktor, yakni: (1) sikap rasisme. Kebencian terhadap satu ras tertentu telah mendorong berbagai tindakan tidak yang adil, penuh kekerasan dari pelbagai konflik sosial-horizontal, (2) sikap etnosentrisme. Sebuah keyakinan bahwa hanya satu kelompok etnis tertentu yang lebih unggul yang mempunyai hak kekuasaan. Pluralitas kesukuan menjadi faktor pemicu konflik, ketimbang sebagai peluang kemajuan, (3) warisan sikap feodalisme dan nepotisme. Sikap ini tampaknya masih merupakan sikap yang laten dalam jangka waktu yang lama, (4) sikap hedonisme. Sikap yang mendahulukan kesenangan diri sendiri ketimbang kepentingan orang banyak. Sikap seperti ini berkaitan erat dengan pelbagai bentuk gaya hidup, seperti gaya hidup konsumerisme, gaya hidup boros, gaya hidup mewah, gaya hidup jalan pintas, (5) sikap ekslusivisme. Sikap budaya monologis, iaitu sikap sebuah kelompok budaya yang menutup dan mengasingkan diri mereka dari relasi dan rekasi dengan kelompok-kelompok budaya lain (Pilliang, 2005:371-372). 


\section{Marketing Konservasi}

Provinsi Konservasi yang sedang digaungkan di Papua Barat kini menjadi new icon 'ikon baru' dalam konteks administrasi ke-Indonesia-an. Banyak kalangan menyambut gembira kehadiran provinsi konservasi, namun banyak pula yang masih mempertanyakan kerangka besar alias noken konservasi yang justru dikhuatirkan dapat menimbulkan kerawanan di masyarakat. Untuk itu, marketing konservasi sangat diperlukan dalam rangka mengubah paradigma tentang urgensi kehadiran noken konservasi tersebut. Filosofi marketing konservasi adalah memberikan arah bagaimana noken konservasi dapat dijalankan dengan melihat kebutuhan tata ruang ekologi sosial budaya Papua Barat dalam pusaran Austro-Melanesia. Marketing konservasi didasarkan pada premis bahwa semua perencanaan dan operasional noken konservasi berorientasi pada pola hidup yang layak. Urgensi dalam marketing konservasi ialah (1) menjadikan penduduk Papua Barat sebagai subjek, dan bukan objek bagi kepentingan tertentu, (2) menjadikan masalah konservasi sebagai langkah awal dalam menyusun program prioriti pembangunan, (3) noken konservasi tidak menjamin sebuah kemerdekaan atau kemenangan, tetapi menyediakan tools 'alat' untuk menjaga hubungan manusia dengan alam. Perhatikan tabel marketing konservasi di bawah ini.

Jadual 1: Marketing Konservasi dalam Perspektif Sosial Budaya Austro-Melanesia

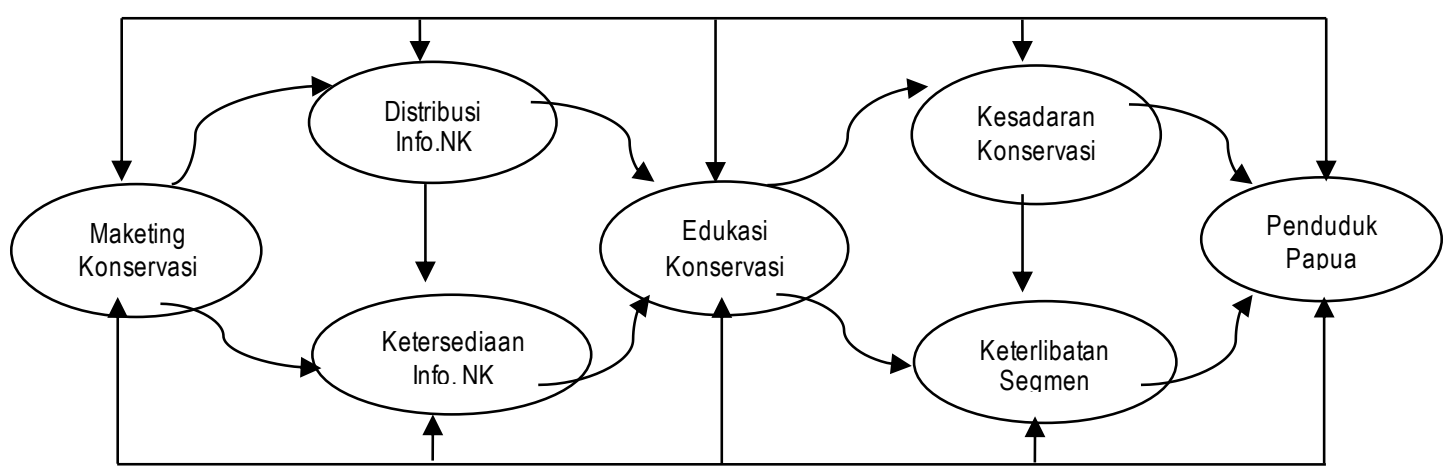

Sumber: Inovasi Warami (2020)

\section{Kesimpulan}

Berdasarkan huraian di atas, maka dapat disimpulkan bahwa Noken Konservasi Sosial Budaya AustroMelanesia di Provinsi Papua Barat sebagai berikut. Pertama, provinsi konsevasi yang dicanangkan pada 19 Oktober 2015 harus menjadi Noken Konservasi bersama dengan keberpihakan pada pusaran prinsip konsevasi budaya Melanesia. Kedua, Endapan Noken Konservasi harus mengandung legitimasi kearifan, kebijaksanaan, pemeliharaan, pemulihan, pengawasan, dan pengendalian atas lingkungan alam (bumi; kawasan; tanah; laut; dusun; kebun; hutan; pulau) bagi penduduk Papua Barat. Ketiga, Noken Konservasi mendapat pengakuan dari penduduk Papua Barat melalui prinsip relasi, interelasi, dan interdependensi. Keempat, Noken Konservasi dapat mempertimbangkan pola dan gaya hidup dalam arus migrasi budaya Austronesia (secara khusus:kapitalisme), Kelima, Noken Konservasi harus terhindar dan terbebas dari tantangan post-environment yang mencakup: (a) sikap rasisme, (b) sikap etnosentrisme, (c) sikap feodelisme dan nepotisme, (d) sikap hedonism, dan (e) sikap ekslisivisme. Keenam, Noken Konservasi harus memiliki marketing konservasi yang menjadikan penduduk Papua Barat sebagai subjek, dan bukan objek kepentingan tertentu.

\section{Rujukan}

Ahimsa Putra, Heddy Shri. (1994). "Antropologi Ekologi: Beberapa Teori dan Perkembangannya” dalam Jurnal Masyarakat Indonesia, 20(4).

Alua, A. Agus. (2006). Karakteristik Agama-Agama Melanesia. Jayapura: STFT FajarTimur.

Bawole Roni \& Hugo Warami. (2016). Naskah Akademik Pengelolaan Perikanan di Kabupaten Teluk Wondama. Manokwari: UNIPA-WWF Indonesia. 
DOI: https://doi.org/10.47405/mjssh.v5i11.535

Duranti Alesandro. (1997). Linguistic Antrophology. Cambridge: Ca mbridge University Press.

Duranti Alessandro. (2000). Linguistic Anthropology. New York: Cambridge University Press.

Dwi Susilo Rachmad K. (2009). Sosiologi Lingkungan. Jakarta: PT Rajagrafindo Persada.

Erari, K. P. (1999). Tanah Kita, Hidup Kita: Hubungan Manusia dan Tanah di Irian Jaya sebagai Persoalan Teologis (Eko Teologi dalam Perpsektif Melanesia). Jakarta:Pustaka Sinar Harapan.

Marit, L. E. \& Hugo Warami. (2015). "Noken Papua: Sumber Industri Kreatif Komunitas Di Tanah Papua" dalam Prosiding Seminar Internasional Daya Litera si dan Industri Krea tif: Digita litas

BahasaSastra, Budaya, dan Pembelajarannya. Jakarta: Penerbit Ombak -Universita s Negeri Jakarta.

Marit, L. E. \& Hugo Warami. (2018). "Noken Papua dalam Industri Kreatif Berbasis Bahasa: Perspektif Perekat Kebinekaan dan Kekuatan Kultural Bangsa Indonesia" dalam Monografi Kongres Bahasa Indonesia IX 2018. Jakarta: Repositori Badan Bahasa Kemendikbud RI.

Piliang Yasraf Amir. (2005). Transpolitika: Dinamika Politik di dalam Era Virtuallitas. Bandung: Jalasutra.

Piliang Yasraf Amir. (2010). Dunia yang Dilipat: Tamasya Melampaui Batas-Batas Kebudayaan. Edisi ke3. Bandung: Jala sutra.

Suka, I. G. (2012). Teori Etika Lingkungan: Antroposentrisme, Ekofeminisme, dan Ekosentrisme. Denpasar: Udayana University Press.

Warami Hugo. (2015). "Kebijakan dan Perlindungan Terhadap Noken di Papua" dalam Prosiding Seminar Internasional Daya Literasi dan Industri Kreatif: Digitalitas Bahasa, Sastra, Budaya, dan Pembelajarannya. Jakarta: Penerbit Ombak - Universitas Negeri Jakarta. 